\title{
Interleukin-6 Production in Posttransplant Lymphoproliferative Disease
}

\author{
Giovanna Tosato, “ Karen Jones, * Mary Kay Breinig, ${ }^{\star}$ H. Penney McWilliams, ${ }^{\star}$ and Jennifer L. C. McKnight ${ }^{\star}$ \\ ${ }^{*}$ Laboratory of Immunology, Center for Biologics Evaluation and Research, Bethesda, Maryland 20892; and ${ }^{\ddagger}$ Department of Infectious \\ Diseases and Microbiology, Graduate School of Public Health, University of Pittsburgh, Pittsburgh, Pennsylvania 15261
}

\begin{abstract}
IL-6, a multifunctional cytokine produced by monocytes, fibroblasts, and endothelial cells, promotes the growth of EBV-immortalized $B$ cells in vitro and renders these cells tumorigenic in athymic mice. In the present study, serum/plasma IL-6 bioactivity was found to be abnormally elevated, albeit transiently, in 17 of 18 solid organ transplant recipients with posttransplant lymphoproliferative disease (PTLD), with a mean maximal level of $196.7 \mathrm{U} / \mathrm{ml}$. This represents a 16.4 increase above the normal mean $(11.3 \mathrm{U} / \mathrm{ml})$. In contrast, only 3 of 10 solid organ transplant recipients with uncomplicated courses posttransplant had abnormally elevated serum/plasma IL-6 bioactivity (mean maximal level $41.4 \mathrm{U} / \mathrm{ml}, P=0.0007$ ). When transferred to single cell culture, the 11 PTLD tissues produced 640 to $1.25 \times 10^{6} \mathrm{IL-6} \mathrm{U} / \mathrm{ml}$ in the culture supernatant, with a mean maximal level of $35,025 \mathrm{IL}-6 \mathrm{U} / \mathrm{ml}$. Cell separation experiments demonstrated that the adherent cells, identified as non-B cells, were the principal source of IL-6 production in vitro by PTLD tissue. Control cultures of inflammatory lymphoid tissue negative for lymphoproliferative disease as well as of PBL from patients with acute EBV-induced infectious mononucleosis consistently produced $<10 \mathrm{IL}-6 \mathrm{U} / \mathrm{ml}$. Thus, IL-6 is produced at high levels by PTLD tissues and may play a critical role in the pathogenesis of PTLD. (J. Clin. Invest. 1993. 91:2806-2814.) Key words: EBV • immunodeficiency • lymphomagenesis • growth factor • tumorigenicity
\end{abstract}

\section{Introduction}

Epstein-Barr virus (EBV), the causative agent of heterophilepositive acute infectious mononucleosis, is a successful pathogen in the human species, asymptomatically infecting most normal adult individuals. Sites of persistent infection include the oropharynx, where EBV is periodically shed, and the peripheral blood, where EBV latently infects a proportion of the B cells (for a review see reference 1 ). When cultured in vitro, these B cells spontaneously give rise to long-term EBV-infected B cell lines (2).

In spite of their potential for unlimited growth, B cells naturally infected with EBV only rarely give rise to lymphoproliferative disease in man. Credit for such successful restraint is attributable, primarily, to $\mathrm{T}$ cell immunity (for reviews see refer-

This work was presented in abstract form at the 1992 Annual Meeting of the Federation for Clinical Research, Baltimore, MD.

Address requests for reprints to Dr. Giovanna Tosato, Center for

Biologics Evaluation and Research, Building 29A, Room 2DO6, 8800

Rockville Pike, Bethesda, MD 20892.

Received for publication 8 September 1992 and in revised form 29 December 1992.

The Journal of Clinical Investigation, Inc.

Volume 91, June 1993, 2806-2814 ences 3,4$)$. Through killing and other suppressor functions, $T$ cells from EBV-seropositive individuals regulate the growth of EBV-infected B cells. Severe T cell immunodeficiency, such as that occurring in AIDS and solid organ transplant recipients, can result in the uncontrolled expansion of B lymphocytes naturally infected with EBV and the development of lymphoproliferative disease (for reviews see references 5, 6). As many as $32 \%$ of solid organ transplant recipients may develop lymphoproliferative disease generally involving EBV-infected B cells (6).

IL-6, a multifunctional cytokine produced by monocytes, fibroblasts, endothelial cells, and other cell types (for a review see reference 7) promotes growth of EBV-infected B cells, acting as an autocrine and/or paracrine growth factor $(8,9)$. In addition, this cytokine has been shown to increase the tumorigenicity of EBV-immortalized B cells in athymic mice $(10,11)$.

In the present study we examined the possibility that IL-6 may play a role in the development of EBV-positive lymphoproliferative disease in immunosuppressed solid organ transplant recipients. To this end, we have measured IL-6 bioactivity in serum/plasma samples of solid organ transplant recipients who developed lymphoproliferative disease or who had uncomplicated courses posttransplant. We also investigated IL-6 production in vitro by the lymphoproliferative lesions.

\section{Methods}

Study population. The study population consisted of 32 patients undergoing solid organ transplantation at the University of Pittsburgh, 20 normal controls, 9 patients with heterophile-positive acute infectious mononucleosis, and 2 patients with AIDS. Relevant clinical data on the transplant patients are shown in Tables I and II. EBV serology was performed by immunofluorescence, as described (12). Patients were diagnosed as having a primary EBV infection by the presence of IgM anti-viral capsid antigen (VCA) ${ }^{1}$ antibodies or the de novo development of IgG anti-VCA antibodies. Patients were diagnosed as having EBV reactivation or reinfection by the presence of a fourfold or higher rise in IgG anti-VCA or anti-early antigen (EA) antibodies (13). The diagnosis of posttransplant lymphoproliferative disease (PTLD, 14) was made when tissue biopsy or autopsy $(a)$ was histologically consistent with a lymphoproliferative process and $(b)$ contained EBV as demonstrated by the detection of EBV nuclear antigens by anti-complement immunofluorescence (15) or of EBV-DNA by Southern blot hybridization with an EcoRI fragment of $\operatorname{EBV}(16,17)$.

Cell cultures. Tissue fragments obtained as biopsy or autopsy specimens were reduced to single cell suspensions by first separating into small fragments and then treating with $1 \mathrm{mg} / \mathrm{ml}$ Collagenase-Dispase (Boehringer Mannheim, Indianapolis, IN) in PBS at $37^{\circ} \mathrm{C}$ for $1-2 \mathrm{~h}$ with rotation. After washing, the cells were suspended at $2-5 \times 10^{6}$ cells $/ \mathrm{ml}$ in tissue culture medium consisting of RPMI 1640 medium

1. Abbreviations used in this paper: EA, early antigen antibodies; PTLD, posttransplant lymphoproliferative disease; VCA, viral capsid antibodies. 


\begin{tabular}{|c|c|c|c|c|c|c|c|}
\hline Patient & Age/Sex & $\begin{array}{l}\text { Transplanted } \\
\text { organ }\end{array}$ & $\begin{array}{l}\text { Major diagnosis } \\
\text { (days)* }\end{array}$ & $\begin{array}{l}\text { EBV serology } \\
\text { pretransplant }\end{array}$ & $\begin{array}{l}\text { EBV infection } \\
\text { posttransplant }^{\ddagger}\end{array}$ & $\begin{array}{l}\text { No samples } \\
\text { tested } \\
\text { (days) }\end{array}$ & $\begin{array}{l}\text { Highest IL-6 } \\
\text { level (day)" }\end{array}$ \\
\hline W.K. & $46 / M$ & Heart & None & Positive & None & $2(133)$ & $20.3(231)$ \\
\hline P.S. & $62 / \mathrm{F}$ & Kidney & None & Positive & None & $8(100)$ & $50.6(101)$ \\
\hline F.S. & $48 / \mathrm{M}$ & Liver & None & Positive & None & $5(51)$ & $53.2(8)$ \\
\hline T.B. & $8 / \mathrm{F}$ & Liver & None & Negative & $\mathbf{P}$ & $6(288)$ & $12.4(54)$ \\
\hline N.G. & $2 / \mathrm{M}$ & Liver & None & Negative & None & $6(649)$ & $10.8(1,29)$ \\
\hline M.J. & $1 / F$ & Liver & None & Negative & None & $5(49)$ & $11.8(1,22)$ \\
\hline E.H. & $46 / F$ & Liver & None & Positive & None & $6(83)$ & $12.6(32)$ \\
\hline R.H. & $23 / \mathrm{M}$ & Kidney & None & Positive & $R / R$ & $7(42)$ & $11.0(27)$ \\
\hline G.H. & $44 / M$ & Kidney & None & Positive & None & $6(215)$ & $8.5(216)$ \\
\hline A.M. & $42 / \mathrm{F}$ & Liver & None & Positive & None & $6(45)$ & $11.1(10)$ \\
\hline K.R. & $2 / F$ & Liver & $\begin{array}{l}\text { Chronic organ } \\
\text { rejection }(0-155)\end{array}$ & Negative & $\mathbf{P}$ & $7(126)$ & $17.0(91)$ \\
\hline H.S. & $33 / F$ & Liver & $\begin{array}{l}\text { Acute organ } \\
\text { rejection }(28-50)\end{array}$ & Positive & None & $6(61)$ & $118.4(43)$ \\
\hline L.S. & $52 / \mathrm{F}$ & Liver & Sepsis $(0-17)$ & Positive & None & $4(56)$ & $103.1(9)$ \\
\hline
\end{tabular}

* Number of days after transplantation condition was apparent.

$\ddagger \mathrm{P}=$ primary infection and $\mathrm{R} / \mathrm{R}=$ reactivation or reinfection, as determined by serology.

${ }^{8}$ Period in days during which samples were obtained.

" Maximum level of IL-6 (U/ml) in samples (day after transplantation sample was obtained).

(Gibco, Grand Island, NY) supplemented with $10 \%$ heat inactivated fetal calf serum, $2 \mathrm{mM} \mathrm{L}$-glutamine, $12.5 \mathrm{U} / \mathrm{ml}$ penicillin, $12.5 \mu \mathrm{g} / \mathrm{ml}$ streptomycin, $0.5 \mu \mathrm{g} / \mathrm{ml}$ amphotericin B (all reagents from Gibco), and $0.5 \mu \mathrm{g} / \mathrm{ml}$ Cyclosporin A (Sandoz Pharmaceutical Co., East Hanover, NJ) in T25 tissue culture flasks (Costar, Cambridge, MA). Cultures were fed once or twice per week and split when appropriate.

Mononuclear cells, obtained by standard techniques from the peripheral blood of patients with acute infectious mononucleosis (18), were cultured at $1 \times 10^{6}$ cells $/ \mathrm{ml}$ in T25 tissue culture flasks containing $5 \mathrm{ml}$ tissue culture medium. Spontaneous outgrowth of EBV-immortalized cells was assessed by microscopy, as described (19).

Assays for IL-6. The murine hybridoma cell line B9 (a gift of Dr. R. Nordan, National Institutes of Health) was used in a standard assay for IL-6 bioactivity (20). $1 \mathrm{U}$ of IL-6 bioactivity in this assay is defined as the activity inducing $1 / 2$ maximal proliferation of B9 cells. An IL-6 concentration of $1 \mathrm{U} / \mathrm{ml}$ corresponds to $\sim 10 \mathrm{pg} / \mathrm{ml}$ of E. coli-derived IL-6 used throughout as a laboratory standard (Sandoz Pharmaceutical Co.) and to $5.5 \mathrm{U} / \mathrm{ml}$ of the NIH interim standard (preparation 88/ 414). Serum/plasma samples were heat-inactivated at $56^{\circ} \mathrm{C}$ for $30 \mathrm{~min}$ prior to testing for IL- 6 bioactivity. Neutralization experiments were performed as previously described ( 8 ). Briefly, serially diluted test samples were incubated in flat bottom 96-well microtiter plates (Costar) for $1 \mathrm{~h}$ at $37^{\circ} \mathrm{C}$ with a purified neutralizing antibody to human IL-6 (mAb IL-6/8, a kind gift of L. Aarden, The Netherlands [21]) at 10 $\mu \mathrm{g} / \mathrm{ml}$. After incubation, the indicator B9 cells were added and IL-6 bioassay carried out as described above. ELISA for human IL-6 (Genzyme, Cambridge, MA) was performed according to the manufacturer's instructions.

Expression of surface determinants. Adherent and suspension cells from PTLD tissue cultures $\left(5 \times 10^{5}\right.$ cells in $0.1 \mathrm{ml}$ PBS containing $5 \%$ FCS) were incubated for $30 \mathrm{~min}$ at $4^{\circ} \mathrm{C}$ either in medium alone or with a fluorescein-labeled goat anti-mouse Ig reagent (Becton-Dickinson, Mountain View, CA) or with a fluorescein-labeled mouse anti-human CD-20 mAb (Coulter Cytometry, Hialeah, FL). After washing, the cells were analyzed on a FACScan ${ }^{\circledR}$ (Becton-Dickinson).

Statistical analysis. Arithmetic means, geometric means, standard errors, standard deviations of the mean, confidence interval, and Fisher's exact test were calculated using conventional formulas.

\section{Results}

Abnormally high serum/plasma IL-6 bioactivity in transplant recipients with lymphoproliferative disease. IL-6 bioactivity was measured by the B 9 cell growth assay in 220 coded serum/ plasma samples from 31 solid organ transplant recipients ( Tables I and II), and compared to that in 20 serum/plasma samples from 20 normal individuals. Organs transplanted included liver (17 patients), kidney ( 10 patients), heart ( 2 patients), lung ( 1 patient), and heart plus lung ( 1 patient). 10 of the 31 solid organ recipients had uncomplicated courses posttransplant, 2 patients were diagnosed with organ rejection, and 1 with Gram negative sepsis (Table I). The remaining 18 patients ( Table II) had posttransplant courses complicated with PTLD (posttransplant lymphoproliferative disease) defined by tissue histology and the presence of EBV-DNA or nuclear antigens (5).

The mean $( \pm$ SD) IL- 6 bioactivity content in 20 normal serum/plasma samples was $11.4(6.4) \mathrm{U} / \mathrm{ml}$ (normal range $\geq$ $7.1 \leq 15.6$ with $99 \%$ confidence interval). Most of the serum/ plasma samples $(157 / 220,71.4 \%)$ from solid organ transplant recipients had a normal IL-6 bioactivity content. The remaining 64 samples had an abnormally high (> $15.6 \mathrm{U} / \mathrm{ml}$ ) IL-6 bioactivity content, 50 of which $(78.1 \%)$ derived from transplant recipients who developed PTLD, 2 from a septic patient, 2 from 2 patients with organ rejection, and 10 from 3 transplant recipients with uncomplicated courses posttransplant.

Levels of IL- 6 bioactivity over time in serum/plasma samples of each of 10 organ transplant recipients with uncomplicated clinical courses post-transplant are depicted in Fig. 1. As shown, seven of these patients had normal IL-6 bioactivity levels throughout. The remaining three patients (W.K., P.S., and F.S.) had serum/plasma samples with IL-6 bioactivity levels two- to threefold above normal, with a mean maximum IL-6 
Table II. Solid Organ Transplant Recipients with Posttransplant Lymphoproliferative Disease

\begin{tabular}{|c|c|c|c|c|c|c|c|}
\hline Patient & Age/Sex & $\begin{array}{c}\text { Transplanted } \\
\text { organ(s) }\end{array}$ & $\begin{array}{l}\text { PTLD location } \\
\text { (day of } \\
\text { diagnosis)* }\end{array}$ & $\begin{array}{l}\text { EBV serology } \\
\text { pretransplant }\end{array}$ & $\begin{array}{l}\text { EBV infection } \\
\text { posttransplant }^{\ddagger}\end{array}$ & $\begin{array}{l}\text { No. samples } \\
\text { tested (days) }\end{array}$ & $\begin{array}{c}\text { Highest level of } \\
\text { IL-6 } \\
\text { (day after } \\
\text { transplant) }\end{array}$ \\
\hline J.R. & $6 / F$ & Heart & $\begin{array}{l}\text { Diffuse at } \\
\text { autopsy } \\
(133)\end{array}$ & Negative & $\mathbf{P}$ & $5(127)$ & $168.4(1)$ \\
\hline G.S. & $56 / \mathrm{M}$ & Liver & $\begin{array}{l}\text { Kidney, lung } \\
\text { node, liver } \\
(50)\end{array}$ & Positive & $R / R$ & $6(97)$ & $1040.0(46)$ \\
\hline E.F. & $52 / \mathrm{F}$ & Liver & $\begin{array}{l}\text { Pancreas, } \\
\text { breast (109) }\end{array}$ & Positive & None & $6(210)$ & $1102.0(173)$ \\
\hline C.A. & $18 / \mathrm{M}$ & Liver & $\begin{array}{l}\text { Tonsils, } \\
\text { adenoids } \\
(78)\end{array}$ & Negative & $\mathbf{P}$ & $14(170)$ & $142.4(43)$ \\
\hline R.W. & $26 / F$ & Liver & $\begin{array}{l}\text { Lymph node } \\
(776,1696)^{\prime}\end{array}$ & Negative & $\mathbf{P}$ & $9(1769)$ & $149.6(1708)$ \\
\hline M.L. & $38 / \mathrm{M}$ & Kidney & $\begin{array}{l}\text { Bone marrow, } \\
\text { brain, } \\
\text { mastoid } \\
(157)\end{array}$ & Positive & $R / R$ & $14(249)$ & $97.7(156)$ \\
\hline J.Y. & $18 / \mathrm{F}$ & Kidney & Brain (162) & Positive & None & $12(293)$ & $84.4(317)$ \\
\hline E.P. & $36 / \mathrm{M}$ & Kidney & Kidney (63) & Positive & $\mathrm{R} / \mathrm{R}$ & $10(41)$ & $93.8(60)$ \\
\hline L.C. & $41 / F$ & Liver & $\begin{array}{l}\text { Lymph nodes, } \\
\text { lung (130) }\end{array}$ & Positive & None & $5(116)$ & $66.1(7)$ \\
\hline A.T. & $18 / \mathrm{M}$ & $\begin{array}{l}\text { Heart/ } \\
\text { Lung }\end{array}$ & $\begin{array}{l}\text { Liver, lung } \\
\text { stomach, } \\
\text { adrenals } \\
(54)\end{array}$ & Negative & $\mathbf{P}$ & $10(300)$ & $190.5(71)$ \\
\hline M.B. & $23 / \mathrm{M}$ & Kidney & Kidney (69) & Negative & $\mathbf{P}$ & $12(91)$ & $19.3(74)$ \\
\hline R.R. & $10 / \mathrm{M}$ & Liver & $\begin{array}{l}\text { Lymph nodes } \\
\quad \text { (62) }\end{array}$ & Negative & $\mathbf{P}$ & $3(52)$ & $56.4(34)$ \\
\hline E.N. & $25 / \mathrm{M}$ & Kidney & $\begin{array}{l}\text { Lymph nodes } \\
\text { (48) }\end{array}$ & Positive & None & $4(29)$ & $38.4(48)$ \\
\hline P.L. & $56 / \mathrm{M}$ & Kidney & $\begin{array}{l}\text { Prostate, } \\
\text { intestine } \\
(195)\end{array}$ & Positive & $R / R$ & $9(303)$ & $18.5(62)$ \\
\hline J.M. & $2 / F$ & Liver & $\begin{array}{l}\text { Lymph node } \\
\text { (143) }\end{array}$ & Positive & None & $4(126)$ & $14.3(156)$ \\
\hline M.S. & $33 / \mathrm{M}$ & Liver & $\begin{array}{l}\text { Lymph nodes } \\
\text { (223) }\end{array}$ & Positive & $R / R$ & $4(382)$ & $28.2(189)$ \\
\hline R.S. & $57 / \mathrm{M}$ & Lung & Lung (102) & Positive & None & $8(167)$ & $30.5(112)$ \\
\hline S.S. & $3 / \mathrm{M}$ & Kidney & $\begin{array}{l}\text { Lymph node } \\
\text { (279) }\end{array}$ & Negative & $\mathbf{P}$ & $11(392)$ & $17.6(280)$ \\
\hline
\end{tabular}

* Number of days after transplantation histologic diagnosis was made.

${ }^{\ddagger} \mathrm{P}=$ primary infection and $\mathrm{R} / \mathrm{R}=$ reactivation or reinfection, as determined by serology.

Period (in days) during which samples were obtained.

" Maximum level of IL-6 U/ml in samples (day after transplantation sample was obtained).

' Patient RW was also diagnosed with Hodgkin's disease on day 1696 posttransplantation.

level of $41.4 \mathrm{U} / \mathrm{ml}$. It should be noted, however, that in two of these patients abnormally high serum/plasma IL-6 levels either preceded the transplant (FS) or both accompanied and followed the transplant (PS).

In contrast to the results in solid organ recipients with uncomplicated clinical courses posttransplant, IL-6 bioactivity was abnormally elevated in serum/plasma samples of 17 out of
18 patients who developed PTLD $(P=0.0007)$, with a mean maximum IL-6 level of $196.7 \mathrm{U} / \mathrm{ml}$ (Fig. 2). Neutralization experiments with an anti-IL-6 mAb (21) demonstrated that IL-6 was responsible for growth stimulation of the indicator B9 cells in all serum/plasma samples (not shown). In most cases, the abnormal elevations of IL-6 bioactivity occurred as spikes separated by periods of normality, reaching levels of IL-6 


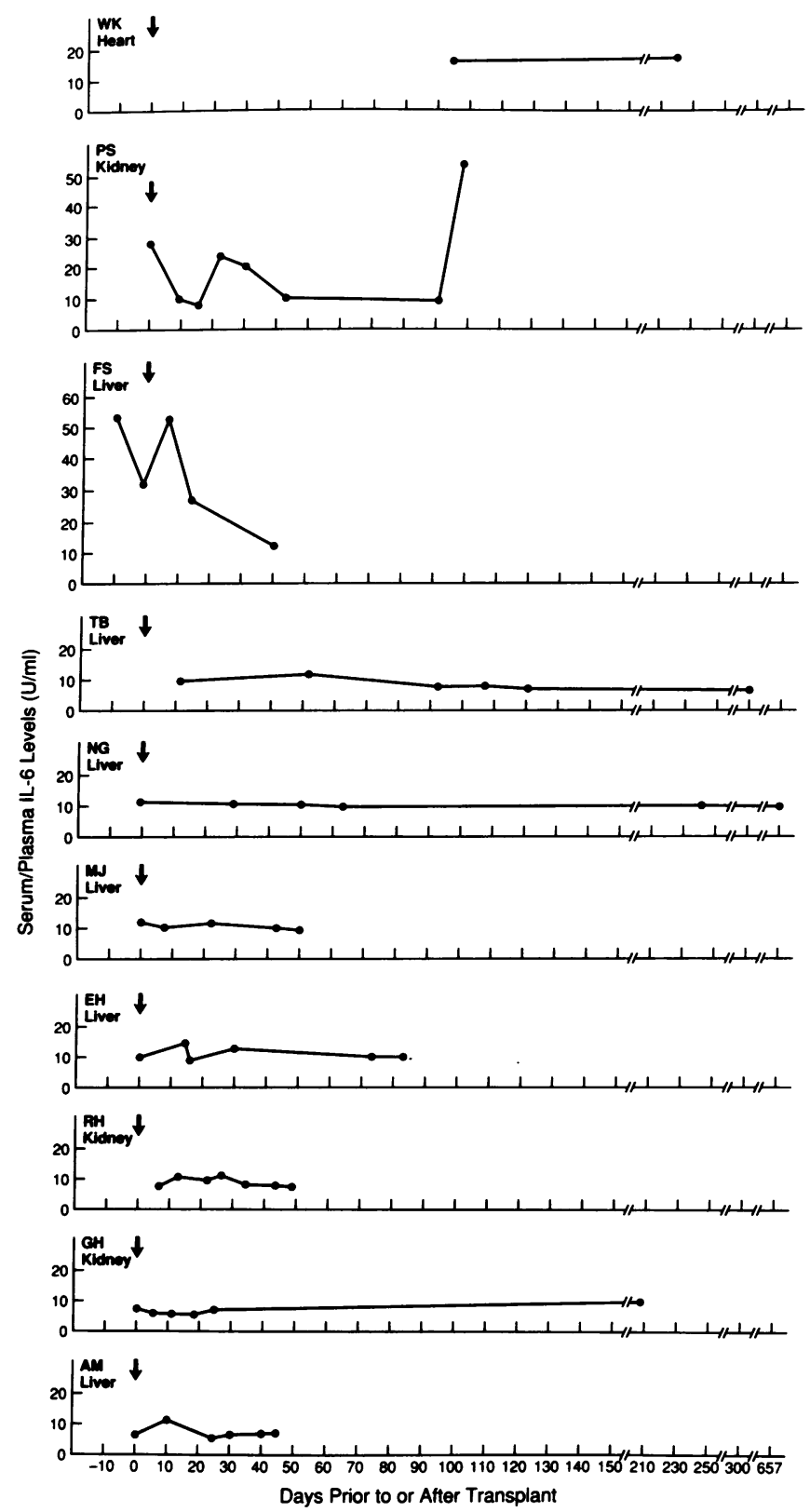

Figure 1. IL-6 bioactivity content in serum/plasma samples of solid organ transplant recipients with uncomplicated courses post-transplant. Serum/plasma samples obtained at various times prior to or after day of transplantation (day 0 ) were tested for IL-6 bioactivity. The results are expressed as $U / \mathrm{ml}$.

bioactivity 5- to 100 -fold above normal. These abnormal spikes of serum/plasma IL-6 bioactivity temporally preceded the diagnosis of PTLD in 11 of 17 cases, and in one case accompanied and in five cases followed the diagnosis of PTLD. Three of these latter five patients had an early diagnosis of PTLD either because of disease location in the brain (J.Y.) or obstructing the biliary track (E.F.), or because PTLD was a coincidental microscopic finding in a rejected organ (M.B.).

Abnormal elevations of serum/plasma IL-6 bioactivity were also observed in three solid organ transplant recipients who developed either organ rejection (H.S. and K.R.) or sepsis (L.P.) (Fig. 3). In all cases, peak serum/plasma IL-6 bioactiv- ity temporally coincided with the clinical diagnosis of organ rejection and sepsis.

There was no correlation between abnormal serum/plasma IL-6 bioactivity in posttransplant recipients and change in EBV status, as determined by serology (Tables I and II). Among the 23 patients with abnormally high serum/plasma IL-6 levels, eight underwent a primary EBV infection at the time of, or shortly after transplant, five had serologic evidence of EBV reactivation or reinfection, and 10 had no serologic evidence of a change in EBV status. Together, these results demonstrated that abnormally high levels of IL- 6 bioactivity in serum of posttransplant recipients generally precede or accompany serious complications such as PTLD, organ rejection, or sepsis.

IL-6 production by PTLD tissue in vitro. The occurrence of abnormally high serum plasma IL-6 bioactivity in patients who developed PTLD prompted us to examine whether the lymphoproliferative tissue was a source of IL-6. To this end, biopsy or autopsy-derived tissue specimens from 10 of the 18 posttransplant recipients diagnosed with PTLD were single-cell suspended, cultured in vitro for 20 to $235 \mathrm{~d}$, and tested for IL-6 secretion in culture over time. For nine of these specimens the earliest conditioned culture medium after PTLD tissue transfer to culture was available for IL-6 testing. As shown (Table III), each of the early culture supernatants contained IL- 6 bioactivity in spite of the fact that the tissue specimens were often very small. It should be noted that these early PTLD conditioned culture media contained 43 to $247,273 \mathrm{IL}-6 \mathrm{U} / \mathrm{ml}$. The remaining two PTLD tissues (J.R. and S.S.), for which no early conditioned media were available for testing, were found to be the two highest IL- 6 producers when first tested after 44 ( 1.9 $\left.\times 10^{6} \mathrm{IL}-6 \mathrm{U} / \mathrm{ml}\right)$ and $126\left(1.25 \times 10^{6} \mathrm{U} / \mathrm{ml}\right)$ days of culture, respectively. Overall, the mean maximum level of IL-6 secreted in the culture supernatant by PTLD tissues was $35,025 \mathrm{U} / \mathrm{ml}$.

Cell cultures of PTLD tissue continued to produce IL-6 at levels comparable to those produced immediately after initiation of culture for at least $20 \mathrm{~d}$. In two cases (J.R. and S.S.) high level IL-6 production in culture continued for 108 and $126 \mathrm{~d}$, respectively.

In contrast to the results with PTLD tissues, the IL- 6 bioactivity content in early culture supernatants of peripheral blood mononuclear cells from 9 patients with acute infectious mononucleosis was less than $10 \mathrm{U} / \mathrm{ml}$ (Table IV). Similarly low $(<10 \mathrm{U} / \mathrm{ml})$ was the IL-6 bioactivity content in three early culture supernatants of single cell suspended lymphoid tissue biopsied for suspected lymphoproliferative disease but found to be negative (Table IV). One of these (G.P.) derived from a solid organ transplant recipient, two from HIV-positive individuals. In vitro IL-6 production continued to be low in peripheral blood mononuclear cell cultures from patients with acute infectious mononucleosis undergoing spontaneous outgrowth in vitro and from the inflammatory lymph nodes. Representative patterns of IL- 6 production over time by PTLD tissue and infectious mononucleosis-derived mononuclear cells are shown in Fig. 4.

The presence of IL-6 in culture supernatants of each PTLD tissue studied was confirmed by a specific ELISA (data not shown ).

In vitro cultures of PTLD tissues were generally composed of suspension cells, identified as B cells by reactivity with an 


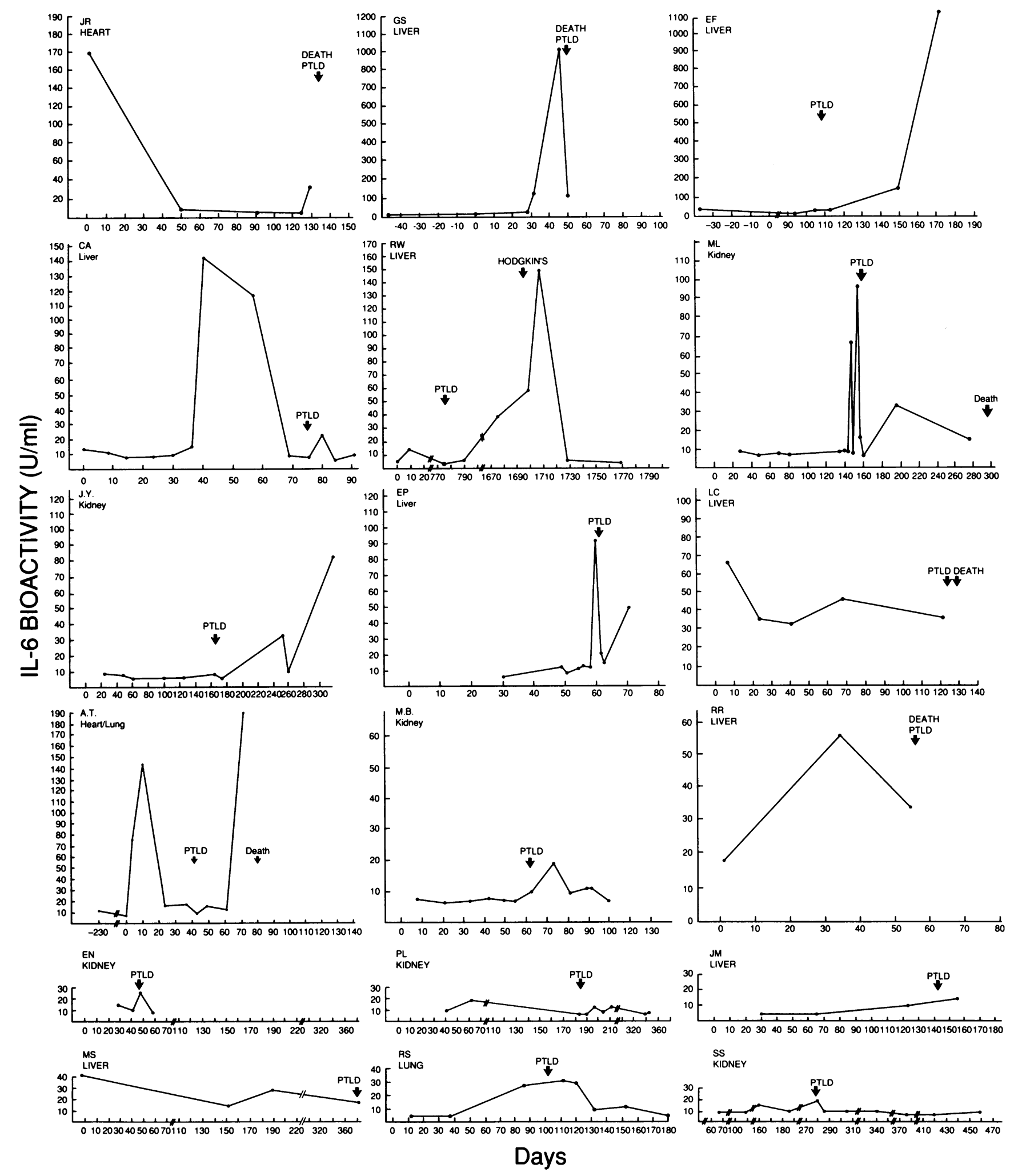

Figure 2. IL-6 bioactivity content in serum/plasma samples of solid organ transplant recipients who developed PTLD. Serum/plasma samples obtained at various times prior to or after the day of transplantation (day 0 ) were tested for IL-6 bioactivity ( $\mathrm{U} / \mathrm{ml}$ ). The arrows indicate the day post-transplant of PTLD diagnosis.

anti-CD20 monoclonal antibody (B1, Coulter Cytometry) and the presence of EBV-DNA $(16,17)$, and of adherent cells unreactive with the same anti-CD20 monoclonal antibody. To investigate the cellular source of IL-6, adherent and suspension cells from three PTLD lesions (J.R., J.M., and S.S.) were cultured either separately or together, and IL-6 secretion was mea- 


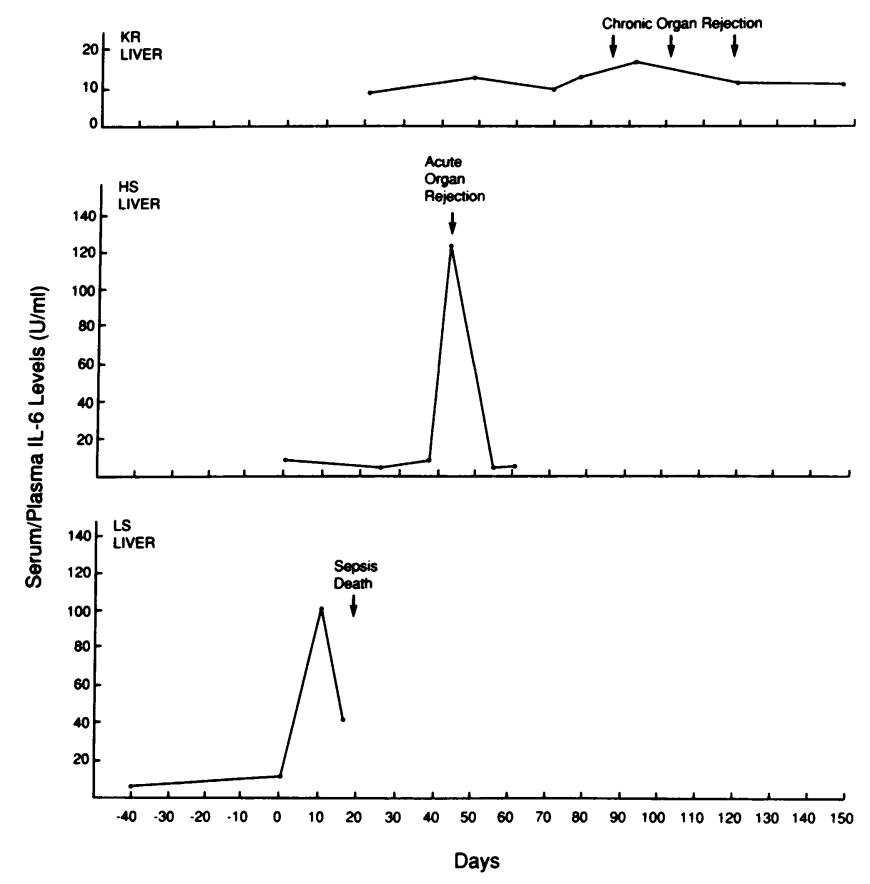

Figure 3. IL-6 bioactivity content in serum/plasma samples of solid organ transplant recipients who developed sepsis or organ rejection. Day 0 indicates the day of transplant; the arrows indicate the day posttransplant of diagnosis with sepsis or organ rejection.

sured over time. As shown (Fig. 5), cultures of unseparated cells from PTLD tissues containing adherent cells together with suspension cells produced large quantities of IL-6 bioactivity, but cultures containing suspension cells alone generally produced little IL-6. In contrast to the suspension cells, cultures containing adherent cells alone produced large quantities of IL-6 bioactivity. The differences in IL-6 levels detected in supernatants of cultures with and without adherent cells could not be attributed to differences in cell densities. The adherent cells, producing high levels of IL-6, were nonproliferating, and were estimated to reach maximum densities of $1 \times 10^{5}$ cells/ $\mathrm{ml}$. The suspension cells, producing low levels of IL-6, were actively proliferating, and reached cell densities of $0.3-1.0$ $\times 10^{6} \mathrm{cells} / \mathrm{ml}$. It should be noted that, after transfer to culture vessels devoid of adherent cells, the PTLD-derived B cells continued to grow at a similar rate (not shown). These findings demonstrate that the PTLD-derived adherent cells, but not the suspension B cells, are capable of high level IL-6 production, and suggest that the adherent cells are the principal source of IL-6 production.

\section{Discussion}

In the present study, we have explored a potential role for IL-6 in the development of lymphoproliferative disease in immunocompromised solid organ transplant recipients. Levels of circulating IL-6 bioactivity were found to be abnormally elevated, albeit transiently, in 17 of 18 transplant recipients who developed PTLD with a mean maximal serum/plasma concentration of $196.7 \mathrm{U} / \mathrm{ml}$. This represents an increase of 16.4-fold above the mean level in normal individuals $(11.3 \mathrm{U} / \mathrm{ml})$. In contrast, only 3 of 10 patients with relatively uncomplicated
Table III. In Vitro IL-6 Production by Posttransplant Lymphoproliferative Disease Tissues

\begin{tabular}{llcrr}
\hline \multicolumn{1}{c}{ Tissue } & Patient & $\begin{array}{c}\text { Initial } \\
\text { IL-6 }(\mathrm{U} / \mathrm{ml}) \\
\text { secreted } \\
\text { (day of } \\
\text { culture) }\end{array}$ & $\begin{array}{c}\text { Total } \\
\text { culture } \\
\text { time } \\
\text { (days) }^{\ddagger}\end{array}$ & $\begin{array}{c}\text { Maximum } \\
\text { IL-6 (U/ml) } \\
\text { secreted } \\
\text { (day of culture) }^{\text {s }}\end{array}$ \\
\hline Lymph node & J.R. & ND" & 235 & $1,900,000(108)$ \\
Breast & E.F. & $422(1)$ & 65 & $832(47)$ \\
Lymph node & R.W. & $247,273(8)$ & 72 & $340,000(13)$ \\
Lymph node & L.C. & $43(8)$ & 69 & $640(54)$ \\
Spleen & R.R. & $7,964(14)$ & 40 & $19,115(20)$ \\
Liver & R.R. & $27,733(13)$ & 20 & $27,733(14)$ \\
Lymph node & E.N. & $503(10)$ & 86 & $935(24)$ \\
Lymph node & J.M. & $59,238(5)$ & 44 & $181,333(16)$ \\
Lymph node & M.S. & $38,229(10)$ & 37 & $63,716(37)$ \\
Lung & R.S. & $18,000(1)$ & 91 & $39,517(44)$ \\
Lymph node & S.S. & ND & 212 & $1,250,000(126)$ \\
& & & &
\end{tabular}

* IL-6 content (U/ml) in initial culture supernatant after transfer to in vitro culture (day of culture in which the supernatant was obtained). * Total number of days in culture during which IL-6 testing was performed.

${ }^{8}$ Highest IL- 6 content $(\mathrm{U} / \mathrm{ml})$ in culture supernatants (day of culture in which the supernatant was obtained).

"Not done, initial culture supernatant not available for testing. The first culture supernatant from PTLD specimen JR was obtained on day 44 of culture and contained $1.9 \times 10^{6} \mathrm{IL}-6 / \mathrm{U} \mathrm{ml}$; the first culture supernatant from PTLD specimen SS was obtained on day 126 of culture and contained $1.25 \times 10^{6} \mathrm{IL}-6 \mathrm{U} / \mathrm{ml}$.

courses posttransplant were found to have abnormally high IL- 6 bioactivity levels in the circulation, with a mean maximal concentration of $41.4 \mathrm{U} / \mathrm{ml}$.

When transferred to culture in vitro, each of 11 lymphoproliferative lesions from 10 transplant recipients secreted large amounts of IL-6 without stimulation with exogenously added mitogens and cytokines. On the average, the IL-6 content in culture supernatants reached levels of $35,025 \mathrm{U} / \mathrm{ml}$. In all cases, the presence of IL- 6 was detected in the initial culture supernatant after transfer of the lymphoproliferative lesions to culture and conditioning for 1-14 d. In contrast, inflammatory lymphoid tissue negative for lymphoproliferative disease secreted low levels of IL-6 when cultured in vitro under identical conditions. Together, these findings suggest that IL- 6 secretion is an intrinsic property of PTLD tissues rather than the result of in vitro stimulation.

It is likely that the lymphoproliferative lesions represent a source of the abnormally high IL-6 bioactivity detected in the patients' circulation. However, high levels of IL-6 secreted by PTLD tissues in vitro generally continued over several weeks while abnormal elevations of IL- 6 bioactivity in the circulation of PTLD patients were transient in many cases. If the lymphoproliferative lesions were the principal source of IL-6 in the patients, PTLD progression in vivo might be expected to cause progressively higher, or at least sustained, levels of IL-6 in the circulation. Several reasons may account for this not occurring. The adherent non-B cell population rather than the EBV-infected B cells appear to be the major contributors of IL-6 secretion in vitro by lymphoproliferative lesions. PTLD progression 


\begin{tabular}{|c|c|c|c|c|c|}
\hline Tissue & Patient & Diagnosis & $\begin{array}{c}\text { Initial IL-6 } \\
\text { (U/ml) secreted } \\
\text { (day of culture) }\end{array}$ & $\begin{array}{l}\text { Total } \\
\text { culture time } \\
(\text { days })^{\ddagger}\end{array}$ & $\begin{array}{l}\text { Maximum IL-6 } \\
\text { (U/ml) secreted } \\
\text { (day of culture) }\end{array}$ \\
\hline Peripheral" blood & F.F. & Infectious mono & $3.4(10)$ & 32 & $3.6(32)$ \\
\hline Peripheral" blood & A.G. & Infectious mono & $7.7(21)$ & 101 & $8.4(37)$ \\
\hline Peripheral" blood & K.K. & Infectious mono & $3.1(15)$ & 29 & $3.3(29)$ \\
\hline Peripheral" blood & J.L. & Infectious mono & $3.3(14)$ & 28 & $3.4(28)$ \\
\hline Peripheral" blood & B.M. & Infectious mono & $6.6(14)$ & 61 & $6.6(14)$ \\
\hline Peripheral" blood & D.N. & Infectious mono & $3.4(15)$ & 15 & $3.4(15)$ \\
\hline Peripheral" blood & J.R. & Infectious mono & $5.3(21)$ & 112 & $5.3(21)$ \\
\hline Peripheral" blood & C.S. & Infectious mono & $3.2(15)$ & 15 & $3.2(15)$ \\
\hline Peripheral" blood & E.F. & Infectious mono & $6.0(19)$ & 84 & $6.0(19)$ \\
\hline Lymph node' & G.P. & Solid organ recipient & $7.6(2)$ & 30 & $7.6(2)$ \\
\hline Lymph node & A.A & AIDS & $7.2(7)$ & 62 & $7.6(6)$ \\
\hline Tonsil' & A.G. & AIDS & $4.6(5)$ & 42 & $4.8(10)$ \\
\hline
\end{tabular}

* IL-6 content $(\mathrm{U} / \mathrm{ml})$ in initial culture supernatant after transfer to culture in vitro (day of culture in which the supernatant was obtained).

* Total number of days in culture during which IL-6 testing was performed.

${ }^{\S}$ Highest IL-6 level (U/ml) in culture supernatants (day of culture in which the supernatant was obtained).

"All peripheral blood samples underwent spontaneous outgrowth of EBV-immortalized B cells in vitro.

'Inflammatory lymphoid tissue.

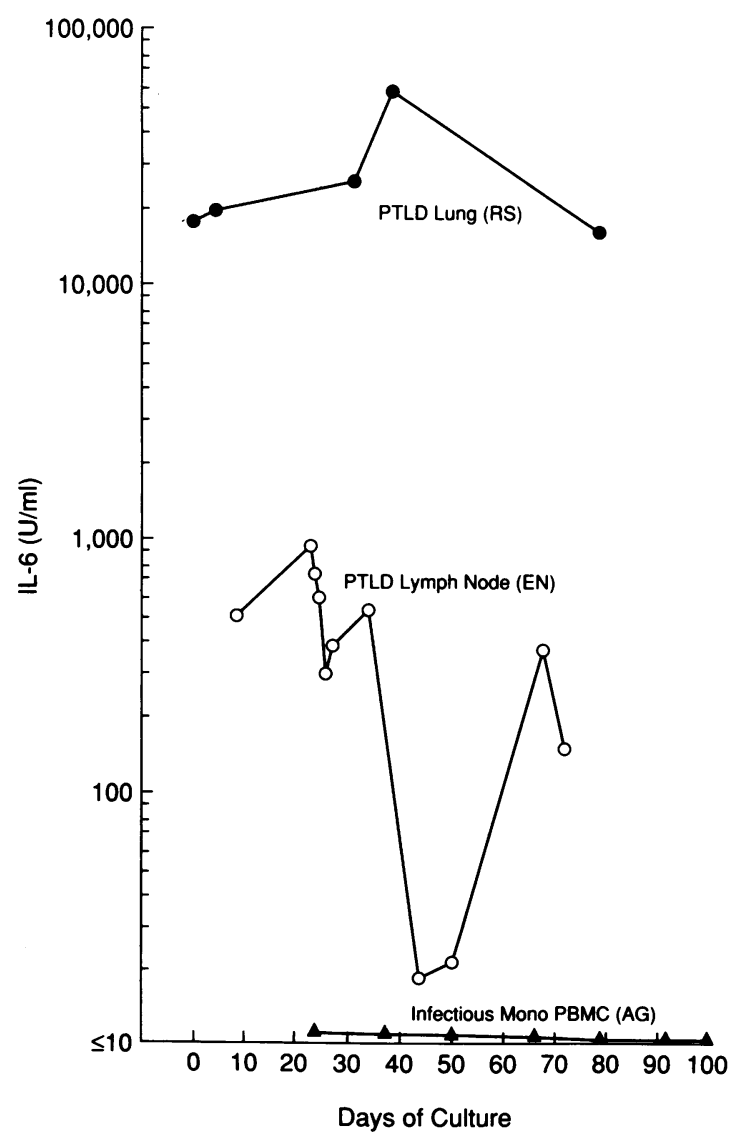

Figure 4. Lymphoproliferative tissues from solid organ transplant recipients secrete IL-6 bioactivity in vitro. Single cell suspended PTLD tissues from transplant patients R.S. and E.N. and PBMCs from infectious mononucleosis patient A.G. were incubated in vitro for the indicated number of days with periodic feeding. Culture supernatants were tested for IL- 6 bioactivity. The results are expressed in IL-6 U/ml. in vivo is thought to be due to uncontrolled growth and subsequent accumulation of EBV-infected B cells $(5,6)$. Endothelial cells and macrophages are present in PTLD tissue specimens because the tumor cells infiltrate vessels and may stimulate migration of reactive cells (22). Thus, disease progression in vivo may not be accompanied by increased or sustained IL-6 production. Furthermore, IL-6 secretion by the lymphoproliferative lesions in vivo may not be reflected in the circulation due to inadequate tissue vascularization (23), local consumption, or degradation. Finally, the biological assay employed to measure IL- 6 may underestimate the cytokine content in serum. Recent work has demonstrated that IL- 6 can exist in plasma/ serum in the form of 100-150- and 400-500-kD complexes that are not readily detectable in the B9 assay (24). Thus, fluctuations in the IL- 6 bioactivity content of PTLD sera may reflect changes in the state of IL- 6 aggregation rather than its concentration.

Previous studies have demonstrated that IL-6 can act as a growth factor for EBV immortalized cells $(8,9)$. These cells secrete IL-6 in the culture supernatant and utilize it as an autocrine growth factor $(8)$. When cultured under conditions that minimize endogenous IL-6 production, EBV-immortalized cells proliferate in response to exogenous IL-6 (9). In addition, retrovirus-mediated transduction of the IL- 6 gene in EBV-immortalized human B cells rendered them tumorigenic in athymic mice, while the parental cells and those clones transduced with a control plasmid were generally nontumorigenic (10, 11). The mechanism of IL-6 tumorigenicity in this experimental system appeared unrelated to a direct oncogenic effect of IL- 6 on the EBV-immortalized cells. Rather, IL-6 at high concentrations appeared to inhibit profoundly cytotoxic functions of the splenocytes, and it was the further reduction of immunity that probably permitted tumor development (11).

The results presented here demonstrate that patients with PTLD generally display abnormally high levels of IL-6 bioactivity while the patients with uncomplicated courses posttrans- 


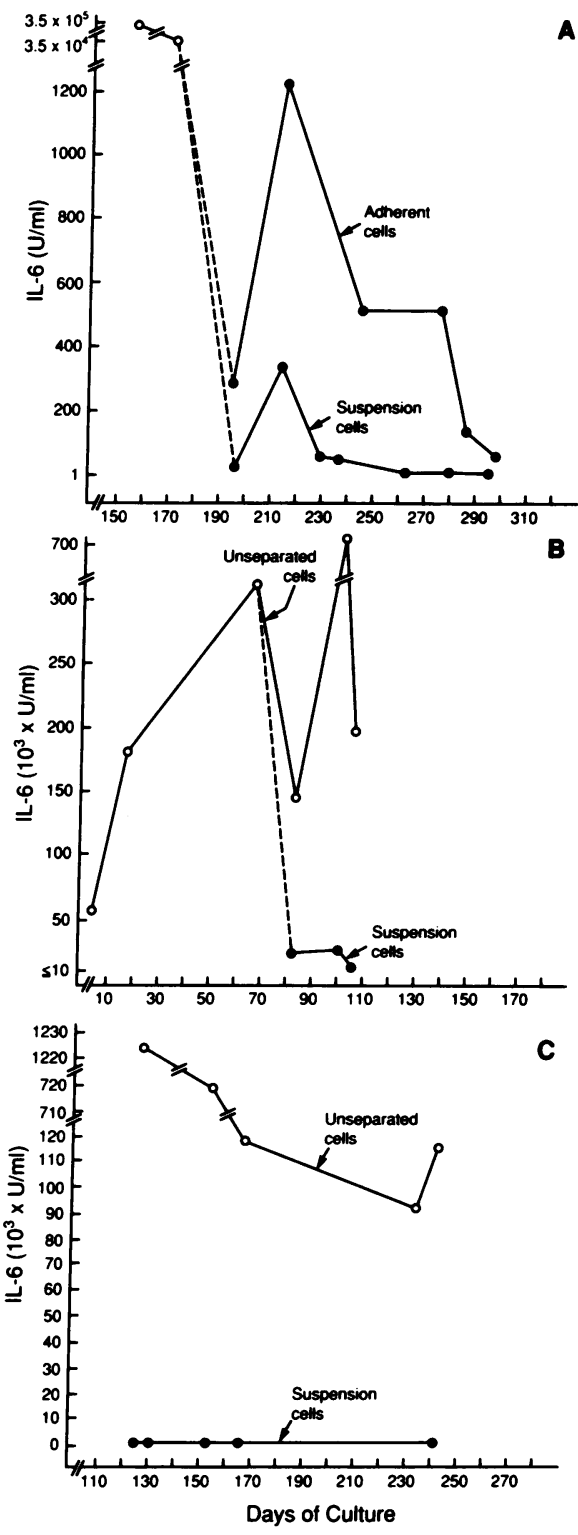

Figure 5. IL-6 bioactivity content in culture supernatants of PTLD tissues. Single cell suspended PTLD tissues from transplant patients J.R. $(A)$, J.M. $(B)$, and S.S. $(C)$ were cultured in vitro for the indicated number of days either as unseparated cell populations or after separation into adherent and suspension cell populations. Culture supernatants were tested for IL-6 bioactivity. The results are expressed in $\mathrm{IL}-6 \mathrm{U} / \mathrm{ml}$.

plant generally do not, and that PTLD lesions spontaneously produce high levels of IL-6 in vitro while inflammatory lymphoid tissues do not. In light of the experimental results linking IL-6 to increased tumorigenicity of EBV-immortalized cells, the present findings suggest that high level IL-6 production may be an important factor in the pathogenesis of PTLD.

The mechanism by which IL-6 may have a tumor-promoting effect in the context of posttransplant immunodeficiency was not addressed here. The cytokine could act directly on the target EBV-infected B cells and promote growth. However, B cells derived from PTLD tissues failed to grow less vigorously in vitro when removed from exposure to IL-6 produced at high levels by the adherent cells, suggesting that IL- 6 may be indirectly tumorigenic. EBV positive lymphoproliferative disease rarely occurs in immunocompetent individuals but has been reported with variable frequencies in immunocompromised patients $(5,6)$. In addition, PTLD can regress with improved immune function achieved by decreasing immunosuppressive medication (25). Thus, host immunity plays an important role in the development and progression of PTLD. As IL-6 further inhibits immune effector functions in already immunodeficient hosts (11), a further reduction of immunity may represent the critical element in the pathogenesis of PTLD.

Previous studies evaluating the concentration of IL-6 in human body fluids, particularly serum, reported that patients with a variety of disease conditions display abnormally high levels of the cytokine, including infection with viruses and various bacteria (26-28), organ rejection after transplantation $(29,30)$, rheumatoid arthritis (31-33), and HIV infection (34, $35)$. Patients with acute EBV-induced infectious mononucleosis do not generally display abnormally high levels of serum IL-6. In recent determinations only 3 of 18 patients with acute infectious mononucleosis were found to have abnormally high serum IL-6 levels (data not shown). There were, however, three posttransplant recipients without PTLD who developed either sepsis or organ rejection, and concomitantly displayed abnormally high serum IL-6 levels. These patients did not develop PTLD. While this raises questions as to the role of IL-6 in the pathogenesis of PTLD, the precise site and mode of IL- 6 production in relation to the EBV-infected cells and immune effector cells may be critical in this patient population.

We have found evidence that the adherent cells are the source of much of the IL- 6 bioactivity secreted in vitro by PTLD tissues. Due to their presence in limited numbers these adherent cells could not be fully phenotyped, except for their failure to express the B-cell specific marker CD20. They could be monocytes, endothelial cells, and/or fibroblasts, cell types known to produce large quantities of IL-6 upon induction with a variety of stimuli, including lipopolysaccharide, IL-1, TNF, and other cytokines $(7,9,36,37)$. Recent studies in AIDS patients have suggested that reactive macrophages and endothelial cells in high grade B cell lymphoma tissues express the IL-6 gene (38). It will be important to identify the cellular source and the mechanisms responsible for IL-6 production within PTLD lesions. However, the information provided here may prove useful in the management of transplant recipients. De novo detection of IL- 6 at abnormally high levels in serum posttransplant should be considered as possibly predictive of PTLD and, in the absence of contraindication, may suggest reduction of immunosuppressive therapy.

\section{Acknowledgments}

The authors wish to thank Ms. Kathy Kulka and Ms. Seema Sridharan for their excellent technical help; Drs. K. Taga and R. Yarchoan for reviewing and Ms. E. Caruso for editing the manuscript.

This research was supported in part by grants BRSG 2 SO7 RR05451-26, BRSG 2 SO 7 RR05451-27, BRSD 2 SO7 RR05451-28, and BRSSIG 2 SO7 RR05451-28 awarded by the Biomedical Research Support Grant Program, Division of Research Resources, National Institutes of Health (to J. L. C. McKnight), and in part by grant 1 PO1 CA47445-02 A2 awarded by the National Cancer Institute (to M. K. Breinig and J. L. C. McKnight). 


\section{References}

1. Miller, G. 1990. Epstein-Barr virus: biology, pathogenesis, and medical aspects. In Virology. B. N. Fields, D. M. Knipe, R. M. Chanock, et al., editors. Raven Press, New York. 1921-1958.

2. Gerber, P., J. Whang-Peng, and J. H. Monroe. 1969. Transformation and chromosome changes induced by Epstein-Barr virus in normal human leukocyte cultures. Proc. Natl. Acad. Sci. USA. 63:740-747.

3. Tosato, G. 1987. The Epstein-Barr virus and the immune system. In Advances in Cancer Research. G. Klein and S. Weinhouse, editors. Academic Press, London. 49-75.

4. Rickinson, A. B. 1990. Cellular immunological responses to the virus infection. In The Epstein-Barr Virus: Recent Advances. M. A. Epstein and B. G. Achong, editors. Wiley Medical Publications, New York. 75-115.

5. Cohen, J. 1991. Epstein-Barr virus lymphoproliferative disease associated with acquired immunodeficiency. Medicine. 70:137-160.

6. Thomas, J. A., M. J. Allday, and D. H. Crawford. 1991. Epstein-Barr virus-associated lymphoproliferative disorders in immunocompromised individuals. Adv. Cancer Res. 57:329-980.

7. Van Snick, J. 1990. Interleukin-6: an overview. Annu. Rev. Immunol. 8:253-278.

8. Tosato, G., G. Tanner, K. D. Jones, M. Revel, and S. E. Pike. 1990. Identification of interleukin-6 as an autocrine growth factor for Epstein-Barr virus-immortalized B cells. J. Virol. 64:3033-3041.

9. Tosato, G., K. B. Seamon, N. D. Goldman, P. B. Sehgal, L. T. May, G. C. Washington, K. D. Jones, and S. E. Pike. 1988. Identification of a monocytederived B cell growth factor as interferon $\beta 2$ (BSF-2, IL-6). Science (Wash. DC). 239:502-504.

10. Scala, G., I. Quinto, M. R. Ruocco, A. Arcucci, M. Mallardo, P. Caretto, G. Forni, and S. Venuta. 1990. Expression of exogenous interleukin-6 gene in human Epstein-Barr virus B cells confers growth advantage and in vivo tumorigenicity. J. Exp. Med. 172:61-68.

11. Tanner, J., and G. Tosato. 1991. Impairment of natural killer functions by interleukin-6 increases lymphoblastoid cell tumorigenicity in athymic mice. $J$. Clin. Invest. 88:239-247.

12. Henle, W., G. Henle, and C. A. Horwitz. 1974. Epstein-Barr virus diagnostic tests in infectious mononucleosis. Hum. Pathol. 5:551-558.

13. Ho, M., G. Miller, R. W. Atchinson, M. K. Breinig, J. S. Dummer, W. Andiman, T. E. Starzl, R. Eastman, B. P. Griffith, R. L. Hardesty, H. T. Bahnson, T. R. Hakala, and J. T. Rosenthal. 1985. Epstein-Barr virus infection and DNA hybridization studies in post-transplantation lymphoma and lymphoproliferative lesions: role of primary infection. J. Infect. Dis. 152:876-886.

14. Ho, M., R. Jaffe, G. Miller, M. K. Breinig, J. S. Dummer, L. Makowka, R. W. Atchison, F. Karrer, M. A. Nalesnik, and T. E. Starzl. 1988. The frequency of Epstein-Barr virus infection and associated lymphoproliferative syndrome after transplantation and its manifestations in children. Transplantation (Baltimore). 45:719-727.

15. Reedman, B. M., and G. Klein. 1973. Cellular localization of an EpsteinBarr virus (EBV) associated complement-fixing antigen in producer and nonproducer lymphoblastoid cell lines. Int. J. Cancer. 11:499-520.

16. Katz, B. Z., N. Roab-Traub, and G. Miller. 1989. Latent and replicating forms of Epstein-Barr virus DNA in lymphomas and lymphoproliferative disease. J. Infect. Dis. 160:589-598.

17. Cen, H., M. K. Breinig, R. W. Atchinson, M. Ho, and J. L. C. McKnight. 1991. Epstein-Barr virus transmission in the donor organs in solid organ transplantation: polymerase chain reaction and restriction fragment length polymorphism analysis of IR2, IR3, and IR4. J. Virol. 65:476-980.

18. Tosato, G., I. T. Magrath, and R. M. Blaese. 1982. T cell-mediated immunoregulation of Epstein-Barr virus (EBV) induced B lymphocyte activation in EBV-seropositive and EBV-seronegative individuals. J. Immunol. 128:575-579.

19. Tosato, G., R. M. Blaese, and R. Yarchoan. 1985. Relationship between immunoglobulin production and immortalization by Epstein-Barr virus. J. Immunol. 135:959-964.

20. Aarden, L. A., E. R. DeGroot, D. L. Schaap, and P. M. Lansdorp. 1987. Production of hybridoma growth factor by human monocytes. Eur. J. Immunol. 17:1411-1416.
21. Henlle, M., L. Boeije, E. de Groot, A. De Vos, and L. Aarden. 1991. Sensitive ELISA for interleukin-6. Detection of IL-6 in biological fluids: synovial fluids and sera. J. Immunol. Methods. 138:47-56.

22. Yousem, S. A., P. Randhawa, J. Locker, I. L. Paradis, J. A. Dauber, B. P. Griffith, and M. A. Nalesnik. 1989. Post-transplant lymphoproliferative disorders in heart-lung transplant recipients. Primary presentation in the allograft. Hum. Pathol. 20:361-389.

23. Nalesnik, M. A., R. Jaffe, T. E. Starzl, A. J. Demetris, K. Porter, J. A. Burnham, L. Makowka, M. Ho, and J. Locker. 1988. The pathology of posttransplant lymphoproliferative disorders occurring in the setting of cyclosporin A-prednisone immunosuppression. Am. J. Pathol. 133:173-192.

24. May, L. T., H. Viguet, J. S. Kenney, N. Ida, A. C. Allison, and P. B. Sehgal 1992. High levels of "complexed" interleukin 6 in human blood. J. Biol. Chem. In press.

25. Frei, K., T. P. Leist, A. Meager, P. Gallo, D. Leppert, R. M. Zinkernagel, and A. Fontana. 1988. Production of B-cell stimulatory factor and interferon $\gamma$ in the central nervous system during viral meningitis and encephalitis. Evaluation in a murine model of infection and in patients. J. Exp. Med. 168:449-453.

26. Wagge, A., P. Brandtzarg, A. Halstenson, P. Kierult, and T. Espevik. 1989. The complex pattern of cytokines in humans from patients with meningococcal septic shock. J. Exp. Med. 169:333-338.

27. Helfgott, D. C., S. B. Tatter, U. Santhanam, R. H. Clarick, N. Bhardwaj, L. T. May, and P. B. Sehgal. 1989. Multiple forms of IFN- $\beta 2 /$ IL-6 in serum and body fluids during acute bacterial infection. J. Immunol. 142:948-953.

28. Fong, Y., L. L. Moldawer, M. Marano, H. Wei, S. B. Tatter, R. H. Clarick, U. Santhanam, D. Sherris, L. T. May, P. B. Sehgal, and S. B. Lowry. 1989. Endotoxemia elicits increased circulating $\beta 2$-IFN/IL-6 in man. J. Immunol. 142:2321-2324

29. Van Oers, M. H. J., A. A. P. A. M. Van Der Heyden, and L. A. Aarden. 1988. Interleukin-6 (IL-6) in serum and urine of renal transplant recipients. Clin. Exp. Immunol. 71:314-319.

30. Symington, F. W., B. E. Symington, P. Y. Liu, H. Viguet, U. Santhanam, and P. B. Sehgal. 1991. The relationship of serum IL-6 levels to acute graft-versushost disease and hepatorenal disease after human bone marrow transplantation. Transplantation (Baltimore). In press.

31. Houssiau, F., J. P. Devogelaer, J. Van Damme, C. Nagant de Deuxchaisnes, and J. Van Snick. 1988. Interleukin-6 in synovial fluid and serum of patients with rheumatoid arthritis and other inflammatory arthritides. Arthritis Rheum. 31:784-788.

32. Bardwaj, N., U. Santhanam, L. L. Lau, S. B. Tatter, J. Ghrayeb, H Rivelis, R. M. Steinman, P. B. Sehgal, and L. T. May. 1989. Interleukin-6, interleukin- $\beta 2$ in synovial effusions of patients with rheumatoid arthritis and other arthritides: Identification of several isoforms and studies of cellular sources. $J$. Immunol. 143:2153-2159.

33. Hirano, M., T. Matsuda, M. Turner, N. Miyasaka, G. Buchan, B. Tang, K. Sato, M. Shimizu, R. Maini, M. Feldmann, and T. Kishimoto. 1988. Excessive production of interleukin 6/B cell stimulatory factor-2 in rheumatoid arthritis. Eur. J. Immunol. 18:1797-1801.

34. Breen, E. C., A. R. Rezai, K. Nakajima, G. N. Beall, R. Mitsuyasu, T. Hirano, T. Kishimoto, and O. Martinez-Maza. 1990. Infection with HIV associated with elevated IL-6 levels and production. $J$. Immun. 144:480-484.

35. Birx, D., R. R. Redfield, K. Tenler, A. Fowler, D. S. Burke, and G. Tosato 1990. Induction of interleukin-6 during immunodeficiency virus infection Blood. 76:2303-2310.

36. Astaldi, G., M. Janssen, P. Lansdorp, C. Williams, W. Zeijlemaker, and F. Costerhof. 1980. Human endothelial culture supernatant HECS: a growth factor for hybridomas. J. Immunol. 125:1411-1414.

37. Kohase, M., D. Henriksen-DeStefano, L. T. May, J. Vilcek, and P. B. Sehgal. 1986. Induction of $\beta 2$-interferon by tumor necrosis factor: a homeostatic mechanism in the control of cell proliferation. Cell. 45:659-664.

38. Emilie, D., J. Coumbaras, M. Raphael, O. Devergne, H. J. Delecluse, C. Gisselbrecht, J. F. Michiels, J. VanDamme, T. Taga, T. Kishimoto, M. C. Crevon, and P. Galanaud. 1992. Interleukin-6 production in high-grade B lymphomas: correlation with the presence of malignant immunoblasts in acquired immunodeficiency syndrome and in human immunodeficiency virus-seronegative patients. Blood. 80:498-504. 